bioRxiv preprint first posted online Sep. 26, 2019; doi: http://dx.doi.org/10.1101/783480. The copyright holder for this preprint (which was not peer-reviewed) is the author/funder, who has granted bioRxiv a license to display the preprint in perpetuity.

All rights reserved. No reuse allowed without permission.

\title{
1 A dynamic pattern of local auxin sources is required for root regeneration
}

2 Rotem Matosevich ${ }^{1}$, Itay Cohen ${ }^{1}$, Naama Gil-Yarom ${ }^{1}$, Abelardo Modrego ${ }^{1}$, Carla Verna ${ }^{2,3}$,

3 Enrico Scarpella ${ }^{2}$ and Idan Efroni ${ }^{1,4}$

$4 \quad{ }^{1}$ Institute of Plant Sciences and Genetics in Agriculture, Faculty of Agriculture, The Hebrew

5 University of Jerusalem, Rehovot, Israel

$6 \quad{ }^{2}$ Department of Biological Sciences, University of Alberta, Edmonton AB T6G 2E9, Canada

$7 \quad{ }^{3}$ Present Address: California Institute of Technology, Pasadena, CA 91125, United States

$8 \quad{ }^{4}$ Corresponding author: Idan Efroni (idan.efroni@mail.huji.ac.il)

\section{Abstract}

Following removal of its stem cell niche, the root meristem can regenerate by recruitment of remnant cells from the stump. Regeneration is initiated by rapid accumulation of auxin near the injury site but the source of this auxin is unknown. Here, we show that auxin accumulation arises from the activity of multiple auxin biosynthetic sources that are newly specified near the cut site and that their continuous activity is required for the regeneration process. Auxin synthesis is highly localized and PIN-mediate transport is dispensable for auxin accumulation and tip regeneration. Roots lacking the activity of the regeneration

20 competence factor $E R F 115$, or that are dissected at a zone of low-regeneration potential, fail 21 to activate local auxin sources. Remarkably, restoring auxin supply is sufficient to confer 22 regeneration capacity to these recalcitrant tissues. We suggest that regeneration competence relies on the ability to specify new local auxin sources in a precise spatio-temporal pattern. 


\section{Introduction}

Continuous plant growth is supported by the activity of meristems, a complex, multi-tissue organ that houses the stem cell niche (SCN), which in turn is organized around a group of cells with low mitotic activity called the quiescent center (QC) (Heidstra and Sabatini, 2014)). Remarkably, ablation or excision of the $\mathrm{SCN}$, including the $\mathrm{QC}$, results in complete meristem regeneration within a few days (Feldman, 1976; Reinhardt et al., 2003; Xu et al., 2006; Sena et al., 2009; Efroni, 2018). This process is best studied in the root meristem, where excision of the entire root tip triggers rapid de novo specification of a $\mathrm{SCN}$ from multiple remaining differentiated cells at the stump (Efroni et al., 2016). The process is controlled by regeneration competence factors, such as ERF115 (Heyman et al., 2016; Zhou et al., 2019), as well as multiple plant hormones (Efroni et al., 2016; Heyman et al., 2016; Zhou et al., 2019). Key to root tip regeneration is the activity of auxin (Sena et al., 2009; Efroni et al., 2016). (indole-3-acetic acid; IAA), one of the main phytohormones in plants which plays a role in many plant developmental processes (Weijers and Wagner, 2016). Auxin is synthesized from tryptophan via TRYPTOPHAN AMINOTRANSFERAS OF ARABISOPSIS 1 (TAA1), producing indole-3-pyruvate, which then undergoes decarboxylation by $Y U C C A(Y U C)(Z h a o$, 2010). In its reduced form, IAA can enter the cell either via diffusion or via the influx carriers AtAUX1-LAX. However, its efflux is mainly mediated by PIN-FORMED (PIN) family transporters which are polarly distributed on the plasma membrane and regulate auxin distribution in plant tissues (Adamowski and Friml, 2015). In the root, auxin is produced in the QC (Petersson et al., 2009; Brumos et al., 2018) and is transported via the PINs to generates a concentration maxima at the SCN (Grieneisen et al., 2007). This maxima serves as an instructive signal for the specification of the distal part of the root (Sabatini et al., 1999). During embryogenesis, PINs transport auxin from multiple marital or embryo-internal sources to its development-relevant position (Robert et al., 2013; Robert et al., 2015).

How auxin concentration is regulated during root regeneration and what is its function in the process is unclear. Following injury, PIN polarization in the stump remained unaltered and while application of the auxin efflux inhibitor 1-N-naphthylphthalamic acid (NPA) (Petrásek et al., 2003) disrupted root meristem regeneration, some growth at the injured tip was still apparent (Sena et al., 2009). Additionally, while injury to plant tissue is often associated with a broad increase in auxin biosynthetic activity (Sztein et al., 2002; Chen et al., 2016; Druege et al., 2016; Xu et al., 2017), the contribution of auxin biosynthesis to auxin accumulation and distribution is unknown.

Here, we utilize tissue and stage-specific inhibition of the auxin biosynthetic machinery in order to dissect the dynamics role of local auxin biosynthesis during tip regeneration. Based 
on this characterization, we analyze recalcitrant tissue and show that regeneration failure stems from the inability to activate local auxin sources at appropriate temporal sequence.

\section{Results}

\section{Auxin biosynthesis is required for root tip regeneration}

To test the role of auxin biosynthesis in root tip regeneration, we first examined mutants of YUC3/5/7/8/9, the main YUC enzymes acting in the root. Quintuple yuc3 yuc5 yuc7 yuc8 yис9 (уисQ) mutants have short roots with very small meristems (Chen et al., 2014a).

Regeneration rates are affected by meristem size, so in order to measure regeneration rates in this background, $y u c Q$ were grown on 5 nM IAA-supplemented plates, which rescued the growth and meristem defects (Chen et al., 2014a). Tips were then cut and seedlings transferred to an IAA-free medium, along with WT controls. Three days post-cut, roots were scored for regeneration of a new root tip. Regeneration rates in $y u c Q$ mutants were reduced compared to WT, an effect that could be recapitulated by post-cut treatment of regenerating roots with YUCCASIN-DF, a competitive inhibitor of YUC (Tsugafune et al., 2017) (Fig. 1A). Similar treatment with the TAA inhibitor L-Kyn (He et al., 2011), led to a dosedependent inhibitory effect on regeneration, with the highest concentration leading to complete abortion of regeneration, indicating that auxin biosynthesis is required for root tip regeneration (Fig. 1A). Due to its strong phenotype and complete loss of regeneration capacity, we chose to utilize L-Kyn treatment to further probe the role of auxin biosynthesis in regeneration.

In uncut roots, L-Kyn treatment caused meristems to gradually shrink over a period of several days (Brumos et al., 2018), but after 3 days of L-Kyn treatment, meristematic cells were still present at the root tip and the expression of the auxin response marker DR5 retained its normal expression pattern, albeit with weakened intensity (Fig. 1B-D). In strike contrast, cut root tip were extremely sensitive to L-Kyn treatment and after just $24 \mathrm{~h}$ of treatment, no meristem was apparent and cells appeared fully differentiated (Fig. 1E-G). High-resolution monitoring of DR5, one of the earliest markers of regeneration (Ulmasov et al., 1995; Sena et al., 2009; Efroni et al., 2016), showed remnant DR5 expression in the xylem immediately after the cut (Fig. 1H-I). By 3 hours post-cut (hpc), cells immediately adjacent to the protoxylem began to express DR5 (Fig. 1J) but no such induction was apparent in L-Kyntreated roots (Fig. 1K). By 6 hpc, the DR5 signal expanded laterally from the protoxylem and gradually became restricted to the basal part of the stump, forming a distinct auxin peak by 12-24 hpc. L-Kyn treatment completely inhibited this expansion and DR5 expression remained limited to the xylem, until the root meristem differentiated at $\sim 24 \mathrm{hpc}$ (Fig. 1I-Q; Fig 1E). The lack of early DR5 activation in L-Kyn treated cut roots suggests that auxin 
biosynthesis normally occurs shortly following tip dissection and is responsible for establishment of a new auxin maxima near the cut site.

\section{Continuous auxin biosynthesis is required to prevent premature differentiation and for pattern recovery during regeneration}

To determine whether auxin synthesis is required just to "kick-start" regeneration or whether it is required throughout the process, roots were dissected and allowed to recover on mock plates for varying times prior to or post L-Kyn treatment. An immediate but short (6h) treatment with L-Kyn was associated with a dramatic reduction in regeneration rate, while roots treated for $24 \mathrm{~h}$ failed to recover altogether. Remarkably, treatment with L-Kyn at different time points during regeneration, up until $\sim 72 \mathrm{hpc}$, resulted in regeneration failure, an effect that was mitigated upon addition of IAA to the L-Kyn treatment medium (Fig. 2A). This confirms that the inhibition of auxin biosynthesis, rather than other possible non-specific side effects of L-Kyn, is critical for regeneration and indicates that auxin biosynthesis is required both for early and late stages of regeneration.

In order to understand the specific role of early auxin synthesis a transcriptomic time-series of L-Kyn-treated root tip regeneration was generated by immediately transferring dissected roots to L-Kyn or mock agar plates for $3 \mathrm{~h}$ or $6 \mathrm{~h}$, after which the root meristem stump was isolated and profiled. As a control, intact meristems treated with L-Kyn for $3 \mathrm{~h}$ or $6 \mathrm{~h}$ were isolated and profiled (Supplemental Fig. 1A; Supplemental Table 1). Consistent with the requirement for auxin biosynthesis in early stages of post-cut regeneration, the increased expression of the auxin response genes IAA1/2/3/4 (Weijers and Wagner, 2016) was largely blocked by L-Kyn treatment (Fig. 2B). Further, induction of previously identified early markers of regeneration (Efroni et al., 2016), was attenuated at $3 \mathrm{~h}$ of L-Kyn treatment and fully lost at $6 \mathrm{~h}$, indicating early termination of the regeneration process (Fig. 2C). To identify the processes affected by auxin biosynthesis during regeneration, we first selected only the genes that were specifically modified by L-Kyn in the regenerating roots, as compared to the uncut meristem (Supplemental Fig. 1B; Supplemental Table 1). GO analysis revealed that genes suppressed by the $3 \mathrm{~h} \mathrm{L-Kyn}$ treatment were enriched for wound response, histogenesis and auxin response, while genes suppressed following $6 \mathrm{~h}$ exposure were highly enriched for cell cycle and cytokinesis processes, suggesting that auxin synthesis is required to induce early cell division in the stump (Supplemental Fig. 1C-D). Mapping of the genes modified by $6 \mathrm{~h} \mathrm{L-}$ Kyn treatment onto the gene expression map of the root (Brady et al., 2007) revealed that genes downregulated by L-Kyn treatment were generally enriched in the meristematic zone, especially in the stem-cell-niche region, consistent with L-Kyn inhibition of the formation of a new SCN. In contrast, genes induced by L-Kyn were normally expressed at higher parts of 
130 the meristem and in the elongation zone (Fig. 2D). Taken together, these changes indicate that

131 without auxin biosynthesis, cells in the stump are unable to activate cell cycle programs and

132 seem to undergo precocious differentiation.

133 Later stages (12-72hpc) of regeneration are marked by gradual repatterning of the

134 regenerating tip (Sena et al., 2009; Efroni et al., 2016). The endodermis/QC marker

135 SCARECROW:YFP (SCR:YFP) was monitored to determine whether auxin synthesis is

136 required just for cellular proliferation or also for tissue pattern recovery. During normal

137 regeneration, expression of tissue identity markers is lost near the cut site at 0-24 hpc, and

138 then gradually regained (Efroni et al., 2016). When SCR:YFP plants were allowed to recover

139 for $24 \mathrm{~h}$ and then treated with L-Kyn for an additional $24 \mathrm{~h}$, roots did not establish normal

140 endodermis patterning and resembled roots at $24 \mathrm{hpc}$ stage (Fig. 2E-H), suggesting that at 24-

$14148 \mathrm{hpc}$, auxin biosynthesis is required for proper cell identity recovery. To determine whether

142 the biosynthesis is also required for patterning during later stages of regeneration, we

143 examined the recovery of WOX5, which is normally confined to the QC cells, but during

144 regeneration is broadly expressed in the vicinity of the stele until $\sim 72 \mathrm{hpc}$, when it is regains

145 its proper localization (Fig. 2I-K). Consistent with the role of biosynthesis in repatterning of

146 injured tissue, when WOX5:mCherry roots were transferred to L-Kyn following $48 \mathrm{~h}$ of

147 recovery, localized QC expression was not established and its expression remained diffused

148 (Fig. 2L). In conclusion, auxin biosynthesis is required throughout the regeneration process

149 both for activation of cell proliferation and for pattern recovery, serving different roles at

150 different stages.

\section{Multiple local auxin sources are sequentially induced during regeneration}

152 Auxin is classically thought to be synthesized at the shoot and transported to the root.

153 However, recent evidence suggests that auxin is synthesized much closer to its region of 154 accumulation (Chen et al., 2014a; Brumos et al., 2018). To identify whether the source of

155 auxin required for regeneration is local or remote, cut roots were placed on split plates

156 containing L-Kyn in both sides of the plate and IAA supplied either to the top part of the plant

157 (shoot and top part of the root), or directly to the regenerating tip. Regeneration was restored

158 only when the tip was located in the IAA-containing part of the plate (Fig. 3A), indicating

159 that auxin is likely produced locally during regeneration.

160 During steady-state root meristem growth, auxin is mainly synthesized in the QC (Brumos et 161 al., 2018), which is fully removed upon root tip dissection. To determine the source of auxin 162 during regeneration, we examined the temporal expression of its biosynthetic enzymes TAA 163 and YUCCA. TAA1:TAA1:GFP was found to be expressed in the protoxylem at early stages 164 of regeneration (Fig. 3B-D), consistent with biosynthesis being required for the early 
bioRxiv preprint first posted online Sep. 26, 2019; doi: http://dx.doi.org/10.1101/783480. The copyright holder for this preprint (which was not peer-reviewed) is the author/funder, who has granted bioRxiv a license to display the preprint in perpetuity.

All rights reserved. No reuse allowed without permission.

165 appearance of the DR5 signal next to the xylem (Fig. 1J-K). qRT-PCR of isolated

166 regenerating meristems at $0 \mathrm{hpc}, 3 \mathrm{hpc}, 6 \mathrm{hpc}$ and $16 \mathrm{hpc}$, detected rapid induction of five YUC

167 genes in the regenerating root (Fig. 3E). Curiously, the $Y U C$ exhibited different expression

168 dynamics, with YUC5/7 exhibited transient expression, while the expression of YUC3/8/9

169 gradually increased until $16 \mathrm{hpc}$. Analysis of the expression of a reporter for YUC9,

170 (pYUC9:VENUS-termYUC9), which is normally confined to the root cap (Fig. 3F), revealed

171 that its expression at $16 \mathrm{hpc}$ was localized to the immediate vicinity of the cut site (Fig. 3G-

$172 \mathrm{H}$ ). This localized induction was consistent with the enhanced auxin accumulation above the

173 cut site between 12-24 hpc (Fig. 1N,P; (Efroni et al., 2016)).

174 The gradual establishment of DR5 expression, first at the vicinity of the protoxylem and then

175 at the cut site region, together with the induction of multiple YUC enzymes, suggests

176 activation of multiple distinct auxin sources during regeneration. To test this hypothesis, we

177 generated an artificial miRNA targeting YUC2/3/5/6/7/8/9 (amirYUC) and expressed it using

178 different promoters active during regeneration. Expression of amirYUC under the QC-specific

179 WOX5 promoter, exhibited disorganized QC cell divisions in 9 DAS plants (Fig. 4A-B), but

180 despite WOX5 broad expression in ground tissue during regeneration (Fig. 2J-K; (Efroni et

181 al., 2016)), WOX5:amirYUC plants did not exhibit a significant reduction in regeneration,

182 suggesting that auxin is not provided to the regenerating meristem by a re-established QC

183 (Fig. 4E). To test whether the xylem serves as an auxin source during regeneration, we

184 expressed amirYUC under the AHP6 promoter, which is expressed in the protoxylem and

185 xylem-pole-pericycle before and immediately after the cut, but gradually loses its expression

186 near the cut site by $\sim 24 \mathrm{hpc}$ (Efroni et al., 2016). AHP6:amirYUC plants exhibited mild

187 disruption to QC cell division patterns (Fig. 4C) and in agreement with the xylem serving as

188 an auxin source during regeneration, caused a significant reduction in regeneration rate (Fig.

189 4E). Finally, to test whether an auxin source near the cut site plays a role in regeneration,

190 amirYUC was expressed under the pYUC9 promoter, which in intact meristems, is excluded

191 from the QC (Fig. 3F). YUC9:amirYUC resulted in mild disruption to the cellular

192 organization of the distal meristem (Fig. 4D) and to rare pin-like inflorescence meristems

193 (Supplemental Fig. 2A-B), a phenotype previously observed for yucl yuc4 npyl (Cheng et al.,

194 2007). Remarkably, YUC9:amirYUC had low regeneration rates, comparable to the $y u c Q$

195 mutants (Fig. 5E; Fig. 1A), indicating that this auxin source, possibly acting near the cut site,

196 plays a significant role in regeneration and that, overall, local and dynamic auxin biosynthesis

197 is required to initiate and sustain root regeneration. 
bioRxiv preprint first posted online Sep. 26, 2019; doi: http://dx.doi.org/10.1101/783480. The copyright holder for this preprint (which was not peer-reviewed) is the author/funder, who has granted bioRxiv a license to display the preprint in perpetuity.

All rights reserved. No reuse allowed without permission.

\section{PIN-mediated polar auxin transport is not required for root tip regeneration}

199 During steady state root growth, PINs mediated transport act together with local biosynthesis 200 to maintain the root meristem (Brumos et al., 2018). Similarly, during root regeneration from

201 leaves, auxin synthesis is induced in the leaf, which the PINs are responsible to direct the

202 auxin to the site of root initiation (Chen et al., 2016). Blocking polar auxin transport using

203 NPA was reported to arrest root tip regeneration (Sena et al., 2009) and to better understand

204 the possible effect of PINs on root tip regeneration, we revisited these experiments. As

205 previously reported, NPA treatment caused complete growth arrest of regenerating roots (Fig.

206 5A). However, close examination revealed that proliferation at the cut root tip was not

207 inhibited and that by $72 \mathrm{hpc}$, the regenerating roots resembled uncut NPA-treated roots

208 (Supplemental Fig. 3A-D), suggesting that regeneration may occur even with NPA treatment.

209 To verify that the growth of the tip under NPA represents true regeneration, we used a lineage

210 tracing system to identify whether a new SCN is formed. The new SCN is specified at $24-48$

$211 \mathrm{hpc}$ and is marked by a transition from an endodermal cell to an epidermis stem cell, made

212 evident by lateral cell divisions originating from the endodermis (Fig 5C-D; (Efroni et al.,

213 2016)). NPA treatment did not disrupt the appearance of these lateral divisions and they

214 originated from similar positions as those occurring in mock-treated roots (Fig. 5C-F). Further

215 consistent with proper regeneration, expression pattern recovery of the QC/endodermal

216 marker SCR:YFP and the ground tissue marker J0571 were not affected by NPA treatment,

217 other than a mild delay (Fig. 5G-J; Supplemental Fig. 5E-L). In agreement, expression of

218 DR5 was induced next to protoxylem cells at $3 \mathrm{hpc}$ even when treated with NPA (Fig. 5K)

219 and while by $6 \mathrm{hpc}$ and $12 \mathrm{hpc}$, NPA-treated roots exhibited a broader DR5 expression

220 domain than control plants, by $24 \mathrm{hpc}$, the peak was confined to the distal end of the root tip,

221 similar to control (Fig. 5L-M; Fig. 1N,P).

222 To genetically verify the PINs are not required for root tip regeneration, we tested the

223 regeneration capacity of plants with mutant PIN transporters PIN1/2/3/4/7, which perform

224 partially redundant functions in the root (Blilou et al., 2005). Regeneration rates and meristem

225 morphology of $\operatorname{pin} 1 \operatorname{pin} 2$, pin2 $\operatorname{pin} 3 \operatorname{pin} 4 \operatorname{pin} 7$ and $\operatorname{pin} 1 /+; 2 ; 3 ; 4 ; 7$ were not significantly

226 different than wild type plants (Fig. 5N; Supplemental Fig. 4). Quintuple pin1;2;3;4;7 plants

227 germinated normally, but produced short roots with very small meristems (Supplemental Fig.

228 4) which did not allow for measurement of regeneration rates. However, when carefully cut,

229 regeneration was observed, and the newly formed tip resembled that of NPA-treated

230 regenerating plants (compare Supplemental Fig. 4K with Supplemental Fig. 1D). Finally,

231 assessment of regeneration in mutants in the callosin-like protein $B I G$, which are defective in

232 auxin transport (Gil et al., 2001), showed a new auxin peak formed near the cut site at $6 \mathrm{hpc}$, 
bioRxiv preprint first posted online Sep. 26, 2019; doi: http://dx.doi.org/10.1101/783480. The copyright holder for this preprint (which was not peer-reviewed) is the author/funder, who has granted bioRxiv a license to display the preprint in perpetuity.

All rights reserved. No reuse allowed without permission.

233 similar to regeneration in WT plants (Supplemental Fig. 5). Taken together, genetic and

234 pharmacological evidence suggest that PIN transporters may act to refine auxin distribution

235 during regeneration, but are required neither for auxin peak formation, nor for its distal

236 localization nor for regeneration per se.

237 The regeneration competence factor $E R F 115$ is required for activation of the early

238 auxin response

239 Given that active local auxin biosynthesis is required for root tip regeneration, we

240 hypothesized that factors that regulate regeneration competence may involve, directly or

241 indirectly, in the activation of the auxin biosynthetic machinery. One of the key factors in

242 determining regeneration competence is the AP2-like protein ERF115, which is rapidly

243 induced in the vicinity of the cut site (Fig. 6A) and expression of its dominant negative

244 35S:ERF115-SRDX caused a severe reduction in regeneration capacity (Heyman et al., 2016;

245 Zhou et al., 2019). While ERF115 was induced near the cut site even when auxin biosynthesis

246 was inhibited using L-Kyn (Fig. 6B), ERF115-SRDX plants which fail to regenerate, did not

247 generate a normal auxin signaling peak at $6 \mathrm{hpc}$ (Fig. 6C). Consistently, induction of auxin

248 biosynthesis enzymes was severely attenuated in this mutants, and only YUC3 and YUC7

249 were induced by 6 hpc, with their expression rapidly lost by 16 hpc (Fig. 6D). Remarkably,

250 application of 5nM IAA to the root tip immediately after dissection of 35S:ERF115-SRDX

251 plants, resulted in almost complete recovery of root regeneration potential (Fig. 6E-F),

252 suggesting that the inability to activate biosynthesis in these mutants is responsible for the

253 loss of regeneration capacity.

254 Regulation of auxin levels is required and sufficient to confer regeneration competence

255 to differentiated cells

256 Wild type plants exhibit a gradient of regeneration competence within the meristem, with

257 regeneration rates dropping for cuts performed high in the meristem (Sena et al., 2009; Zhou

258 et al., 2019). To test whether the loss of capacity to activate auxin synthesis underlies this

259 drop in regeneration competence, we cut roots at a distance of $\sim 220 \mu \mathrm{M}$ from the QC, at a

260 zone where almost no regeneration occurs (Sena et al., 2009). Surprisingly, by 6 hpc, a

261 normal auxin peak was apparent in high-cut roots (Fig. 7A). However, this expression was not

262 sustained and by $12 \mathrm{hpc}$, DR5 expression was lost and subsequently, root tips differentiated

263 (Fig. 7B). This suggests that while early sources of auxin may be active in high cut roots, late

264 sources may not be induced. Indeed, qRT-PCR showed that YUC5 and YUC7 was rapidly

265 upregulated but returned to base levels after several hours (Fig. 7C). Curiously, YUC9 was

266 strongly induced early on, but its expression returned to base levels, consistent with previous

267 observations (Fig. 7C; (Xu et al., 2017)). This was in striking contrast to its temporal 
bioRxiv preprint first posted online Sep. 26, 2019; doi: http://dx.doi.org/10.1101/783480. The copyright holder for this preprint (which was not peer-reviewed) is the author/funder, who has granted bioRxiv a license to display the preprint in perpetuity.

All rights reserved. No reuse allowed without permission.

268

269

270

271

272

273

274

275

276

277

278

279

280

281

282

283

284

285

286

287

288

289

290

291

292

293

294

295

296

297

298

299

300

301

expression pattern in low-cut roots, which regenerate normally (Fig. 3E). Application of 5nM auxin to high-cut roots resulted in recovery of the $12 \mathrm{~h}$ auxin peak (Fig. 7D) and in a significant increase in regeneration rates (Fig. 7E), indicating that auxin is not only required but also sufficient to provide regeneration competence to high-cut roots.

\section{Discussion}

\section{Auxin synthesis is required and sufficient for regeneration competence}

Regeneration competence in plants is widespread, but not universal, and it remains unclear why only some tissues are able to undergo complete regeneration. In the meristem, regeneration potential decreases with increasing heights of meristem injury (Sena et al., 2009; Zhou et al., 2019). Here, we show that the loss of competence in high-cut roots is due to the inability to specify and maintain new auxin sources. Interestingly, early auxin responses were induced in high-cut roots and were only lost at $12 \mathrm{hpc}$, suggesting that the cause for the inability to regenerate may not be in the immediate wound response, but rather in a long-term development program dictated by the internal state of cells. This capacity to activate temporal auxin synthesis programs may be a key universal feature of the "regeneration competence" of the tissue. Indeed, the ability of cut Arabidopsis leaves to produce microcalli structures and generate adventitious roots relies on auxin synthesis (Chen et al., 2014b; Chen et al., 2016; Bustillo-Avendaño et al., 2018) and while tissue competence to generate these roots declines with age (Chen et al., 2014b; Xu et al., 2016), it can be restored by auxin application (Chen et al., 2014b).

A key remaining question is what factors control the timing and position of the auxin biosynthetic sources. Some regulators may be direct, such as the wound responsive transcription factor ERF109 or the root maintenance and regeneration regulators PLETHORA, both shown to directly activate auxin biosynthesis (Kareem et al., 2015; Santuari et al., 2016; Bahieldin et al., 2018). Other regulators of auxin synthesis may be indirect, acting via the regulation of other hormones, such as cytokinin (Schaller et al., 2015), or by restricting the transcriptional response profile of the tissue. Indeed, as root tip regeneration process lasts $72 \mathrm{~h}$, during which multiple YUC enzymes are induced in a development-specific manner, it is unlikely that a single "regeneration factor" is responsible for activating auxin synthesis, but rather, a different network of redundant factors may act at different temporal windows.

\section{Auxin transport versus local biosynthesis in tip regeneration}

Polar transport of auxin is a major regulator of auxin distribution within plant tissues (Adamowski and Friml, 2015). However, more recent evidence has suggested that local auxin biosynthesis may play at least an equal role in the process (Brumos et al., 2018; Zhao, 2018). 
302 Our work shows that during tip regeneration, local biosynthesis is the main regulator of auxin

303 accumulation. This may be due to the small number of cells involved in regeneration or due to

304 the need to form a pattern de novo. The latter hypothesis is more compelling, and indeed,

305 recent work on the de novo formation of veins in leaves, thought to be mainly determined by

306 PIN polarization (Scarpella et al., 2006), has shown that PINs may be dispensable for vein

307 formation per se (Verna et al., 2019), while local auxin biosynthesis may play an important

308 role (Kneuper et al., 2017; Ohashi-Ito et al., 2019). It should be noted that while PIN-

309 mediated polar auxin transport may be redundant for regeneration, it does not follow that

310 auxin transport is not a crucial player. Importantly, while auxin synthesis during regeneration

311 occurs very close to the site of regeneration, the process was rescued by external hormone

312 application, suggesting that biosynthesis may be required to establish local auxin

313 concentrations on a tissue level, but some, non-PIN transport mechanisms may act to

314 redistribute auxin inside relevant cells.

315 A complex temporal sequence of hormone synthesis during regeneration

316 Plant development is governed by the relationship between different hormones and their

317 relative activity in specific microenvironments (Schaller et al., 2015). Interestingly,

318 application of a very low $(5 \mathrm{nM}-10 \mathrm{nM})$ auxin concentrations can restore regeneration capacity

319 to L-Kyn treated, ERF115:SRDX plants or high cut plants. How can such a low hormone

320 concentration induce this strong developmental effect? One possibility is that in the context of

321 regeneration, auxin may promote its own synthesis, as observed during vasculature

322 development (Ohashi-Ito et al., 2019), thereby generating a feedback loop that promotes the

323 establishment of an auxin concentration peak near the cut site. It follows that factors

324 controlling the sensitivity of cells to auxin may be just as important in allowing the injured

325 tissue to generate sufficient auxin and promote successful regeneration. This view is

326 supported by the reduced regeneration rates in mutants of the auxin response factor

327 MONOPTROS (Efroni et al., 2016).

328 Plant regeneration and tissue reconstruction is a complex process which involves the activity

329 of multiple factors and hormones. Our work shows that an injury-induced dynamic pattern of

330 auxin sources, which likely integrates many developmental and environmental cues, is crucial

331 for the decision of whether or not to regenerate the injured organ. 


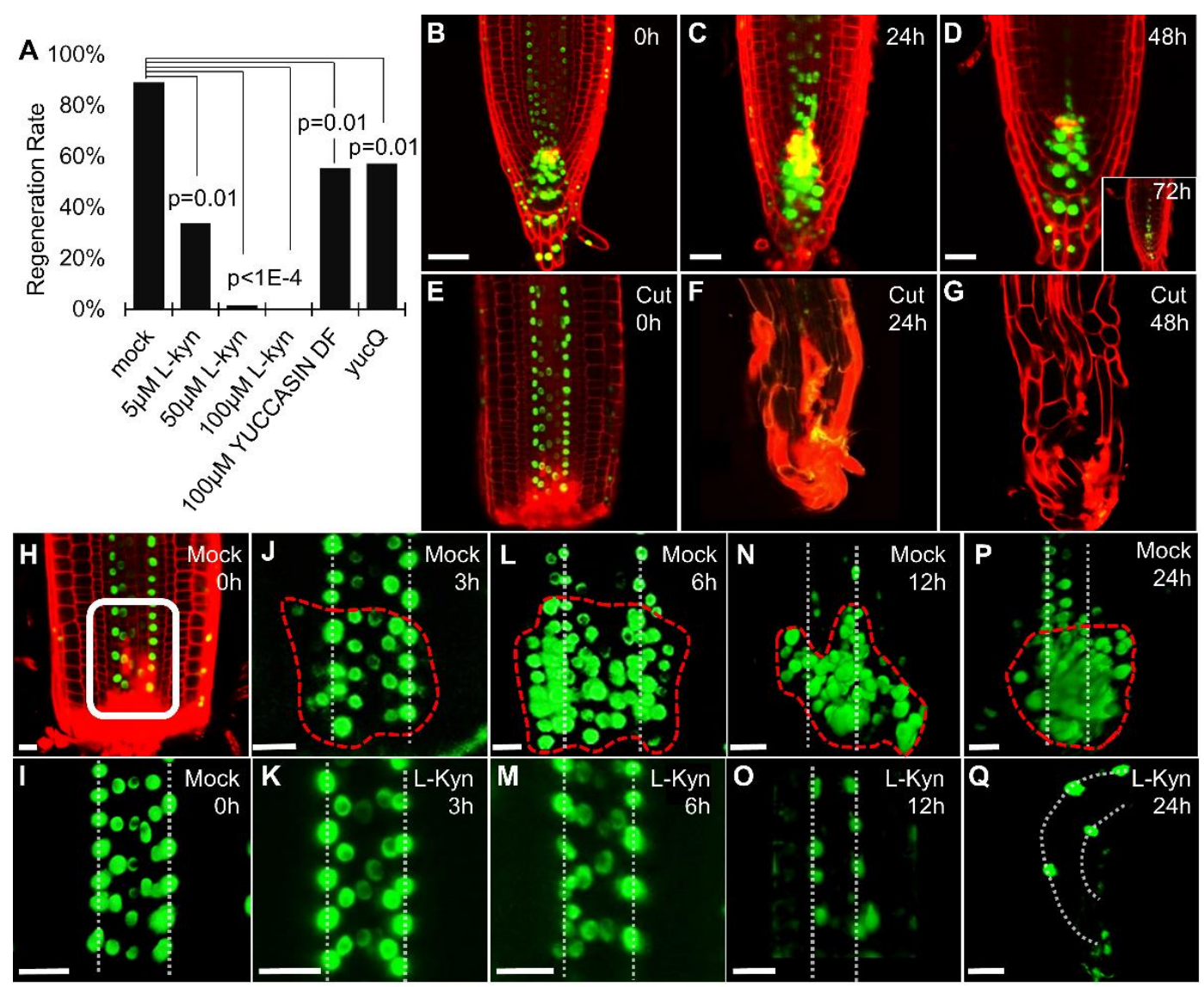

Figure 1. Auxin biosynthesis is required for root tip regeneration. A) Root tip

regeneration rates in plants with disrupted auxin biosynthesis activity, and either treated with

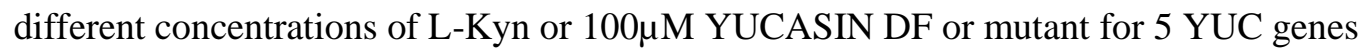
(уисQ) (shown $\mathrm{p}$-values are for Tukey HSD on a logistic regression model; $\mathrm{n}=55,62,65,75$,

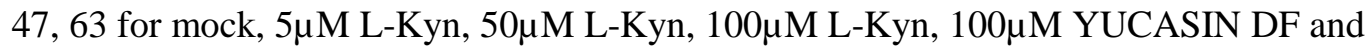
yucQ, respectively). B-G) Confocal time-series of 100 $\mu \mathrm{M}$ L-Kyn-treated DR5rev:3xVENUS$N 7$ plants showing uncut (B-E) or regenerating roots (E-G). H-Q) Expression of pDR5rev:3XVENUS-N7 immediately after dissection (H-I) or during regeneration (J-Q) of tips treated with mock $(\mathrm{J}, \mathrm{L}, \mathrm{N}, \mathrm{P})$ or $100 \mu \mathrm{M}$ L-Kyn $(\mathrm{K}, \mathrm{M}, \mathrm{O}, \mathrm{Q})$. White box in $(\mathrm{H})$ marks the area shown in (I-Q). Dotted vertical lines mark the protoxylem. Dashed red lines mark the

344 forming auxin peak. Propidium iodide was used to stain cell walls (red). Scale bars are 50 $\mu \mathrm{m}$

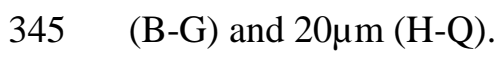



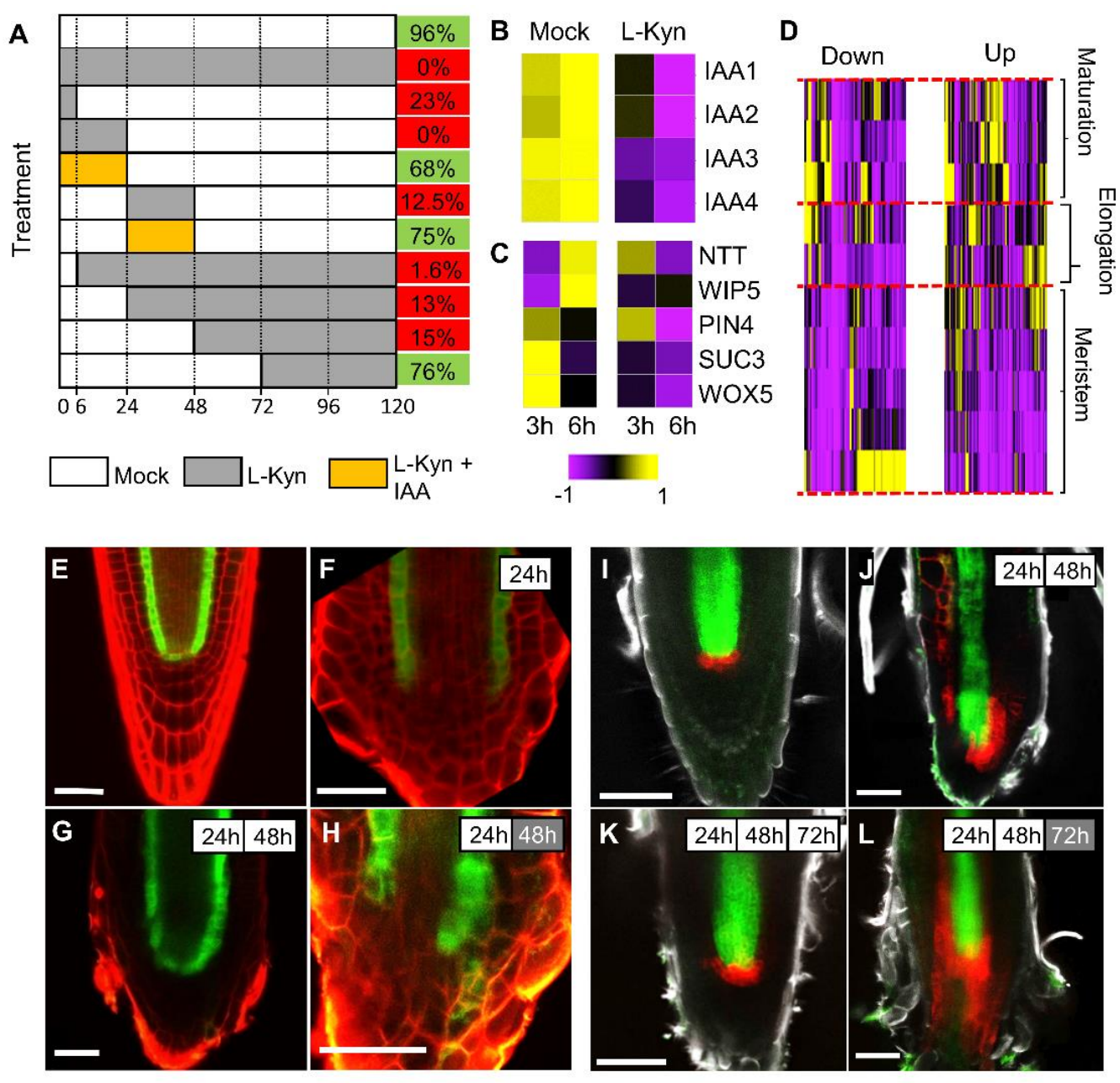

Figure 2. Auxin biosynthesis is required throughout the regeneration process. A)

Regeneration rates of 7 DAS roots at different time points of mock, $100 \mu \mathrm{M}$ L-Kyn or $100 \mu \mathrm{M}$ L-Kyn+100nM IAA treatment. Regeneration rates are shown on the right (Green marks rates of 66\% and up, red is lower than 66\%). B-C) Expression of auxin response genes (B) and regeneration-induced genes (C). D) Expression of genes modified by $6 \mathrm{~h} \mathrm{L-Kyn}$ treatment at different regions of the root. E-L) Confocal images of SCR:YFP (E-H) or WOX5:mCherry $x$

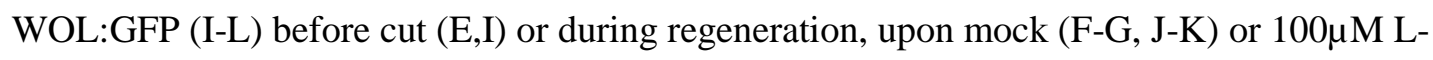
Kyn $(\mathrm{H}, \mathrm{L})$ treatment, at the specified time points. White and gray boxes mark time spent on mock or L-Kyn plates, respectively. Scale bars: $50 \mu \mathrm{m}$. 
A

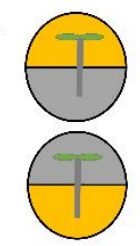

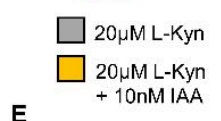
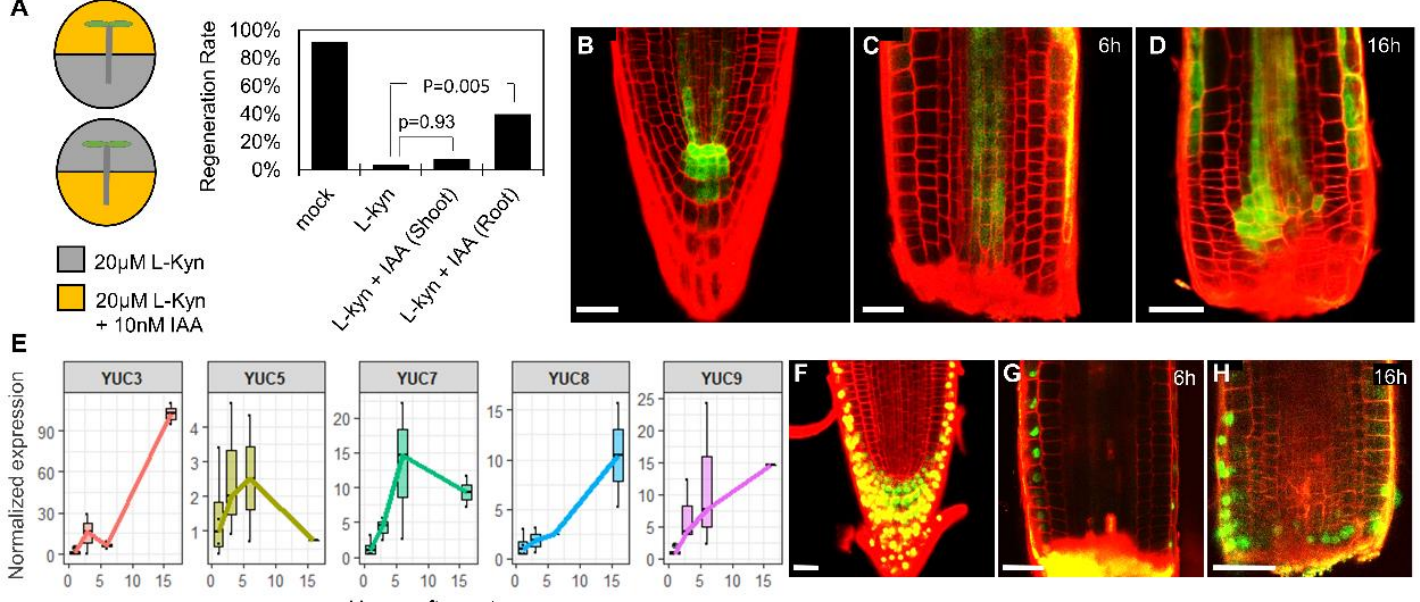

Hours after cut
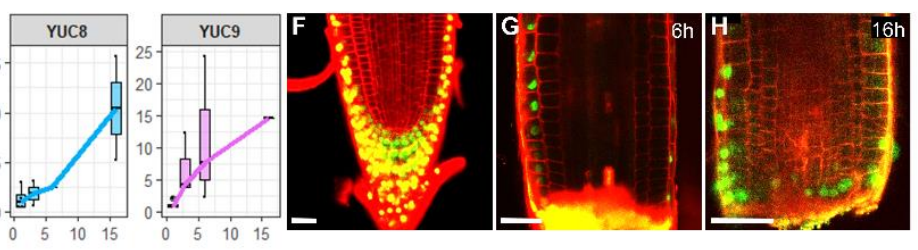

Figure 3. Local auxin synthesis by multiple sources during root tip regeneration. A)

Regeneration rates of 7 DAS roots treated with $20 \mu \mathrm{M}$ L-Kyn and supplemented with $10 \mathrm{nM}$

IAA either at the shoot and upper part of the root or at the lower part of the root (shown pvalues are for Tukey HSD on a logistic regression model; $n=50,50,47,50$ for mock, $20 \mu \mathrm{M}$

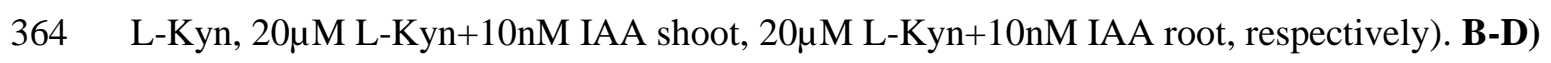
qRT-PCR measurement of YUC genes in isolated meristems of regenerating roots at different time points. Expression was normalized to that of cut meristems isolated immediately after cut. F-H) Confocal images of uncut $(\mathrm{F})$ or regenerating roots $(\mathrm{G}-\mathrm{H})$ expressing pYUC9:VENUS-termYUC9. Scale bars: $20 \mu \mathrm{m}$. 


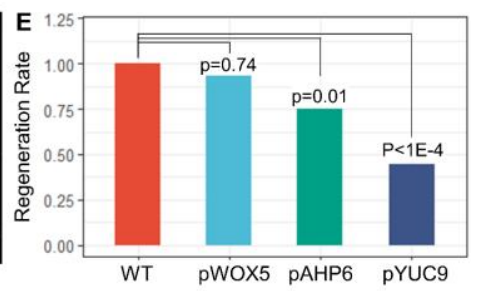

Figure 4. Stage- and tissue-specific knockdown of YUC during regeneration. A-D)

Confocal images of uncut 9 DAS meristem of WT plants (A) or mutants expressing amiRYUC under different tissue-specific promoters (B-D). E) Regeneration rates of mutants expressing amiRYUC under different tissue-specific promoters (shown p-values are for Tukey HSD on a logistic regression model; $\mathrm{n}=154,60,68,23$ for WT, WOX5:amiRYUC, 

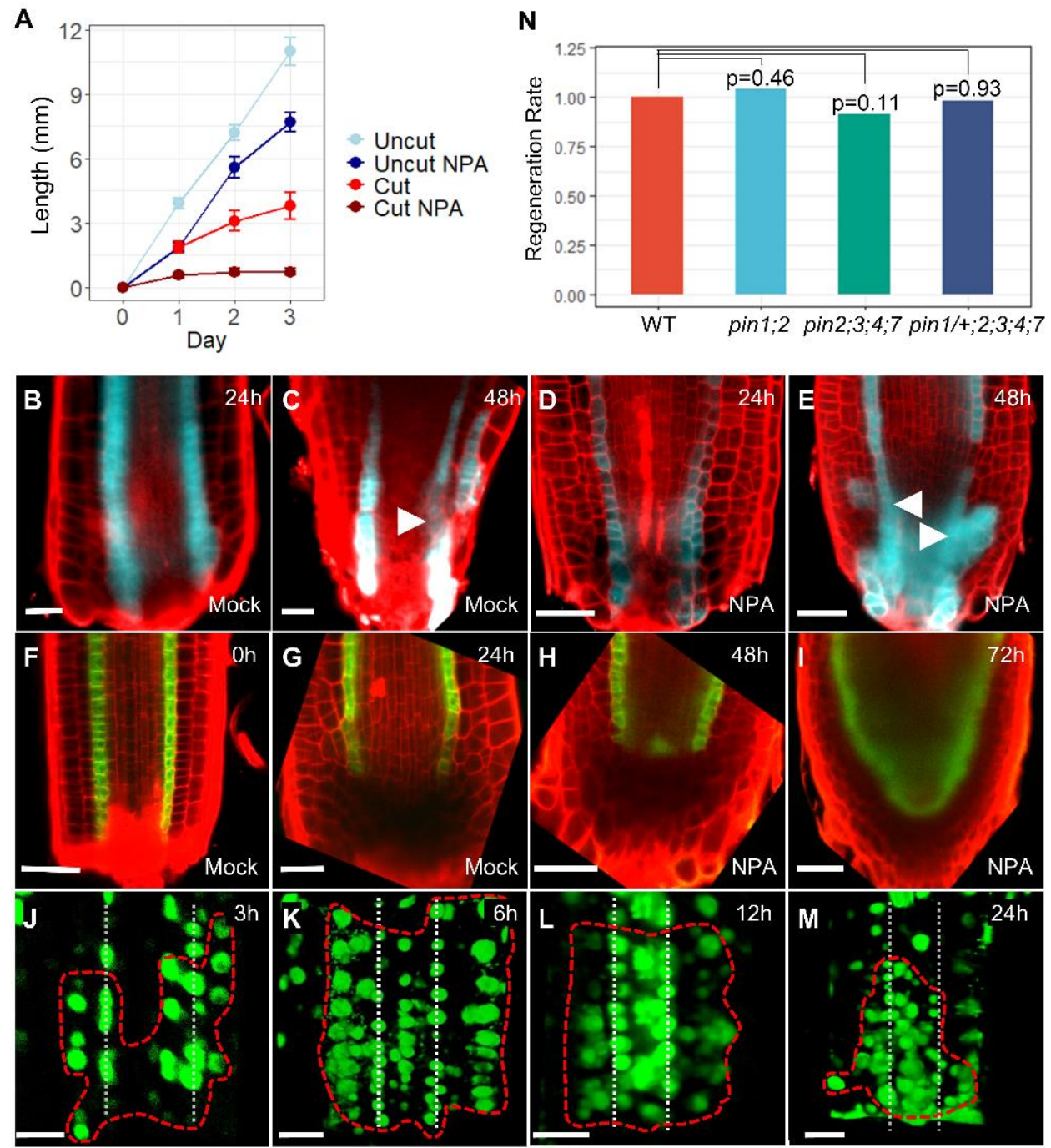

Figure 5. PIN-mediated polar auxin transport is not required for regeneration. A)

Growth of uncut and cut roots transferred at 7 DAS to control or $10 \mu \mathrm{M}$ NPA-supplemented plates. B-I) Confocal images of regenerating root tips carrying lineage CFP-marked clones induced by the $S C R$ promoter (B-E) or expressing the labile $S C R: Y F P$ reporter (F-I), allowed to regenerate on mock (B-D, F-G) or 10 $\mu$ M NPA-supplemented plates (D-E, H-I). Arrowheads mark the origin of lateral divisions. J-M) Close-up of the regeneration region of DR5rev:3xVENUS-N7 plants treated with 10 $\mu$ M NPA. Dotted vertical lines mark the protoxylem; compare to Fig. 1H-Q. N) Regeneration rates of pin mutants. No significant change in regeneration rate was observed (p-values are for Tukey HSD on a logistic regression model; $\mathrm{n}=74,74,85,28$ for $\mathrm{WT}$, pin $1 ; 2$ and pin2;3;4;7, and pin1/+;2;3;4;7, respectively). Scale bar: $50 \mu \mathrm{m}$. 

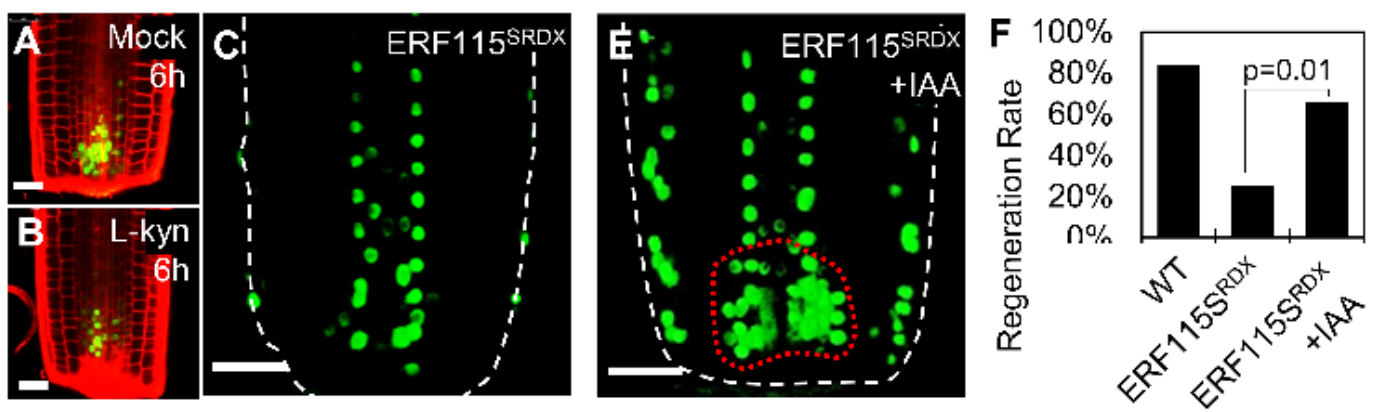

D
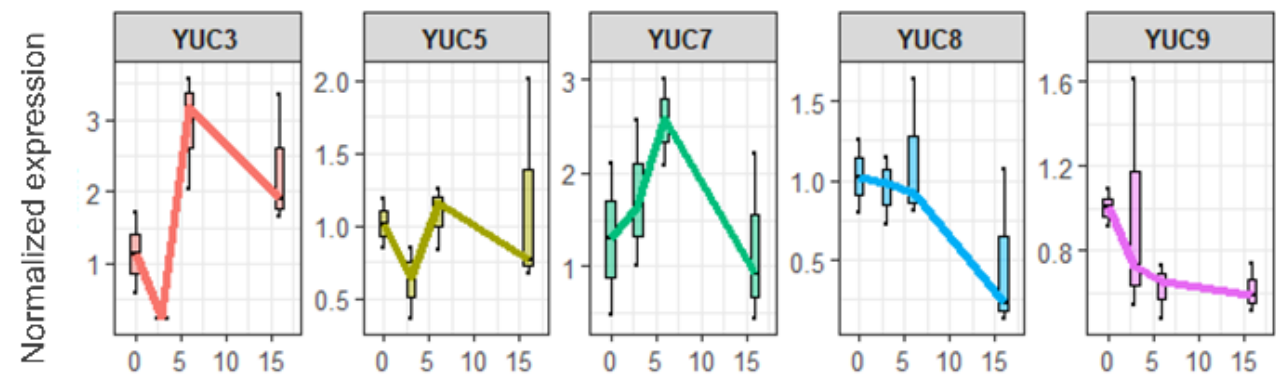

393

Hours after cut

394 Figure 6. Auxin synthesis in regenerating ERF115 dominant negative plants. A-B)

395 Confocal images of ERF115:GFP in regenerating roots treated with mock (A) or 100 $\mu \mathrm{M} \mathrm{L-}$

396 Kyn (B). C) Confocal images of 35S:ERF115-SRDX DR5rev:3xVENUS-NLS roots at 6 hpc.

397 D) qRT-PCR measurement of YUC expression in isolated meristems of regenerating

398 35S:ERF115-SRDX roots. Expression was normalized to that of isolated meristems

399 immediately after cut. E) Confocal images of 35S:ERF115-SRDX DR5rev:3xVENUS-NLS

400 root treated with 5nM IAA at $6 \mathrm{hpc}$. F) Regeneration rates of 35S:ERF115-SRDX 7 DAS

401 roots on mock or 5nM IAA (p-values are for Tukey HSD on a logistic regression model;

402 $\mathrm{n}=115,181,182$ for WT, 35S:ERF115-SRDX on mock and 35S:ERF115-SRDX on 5nM IAA,

403 respectively). Scale bar: $50 \mu \mathrm{m}$. 

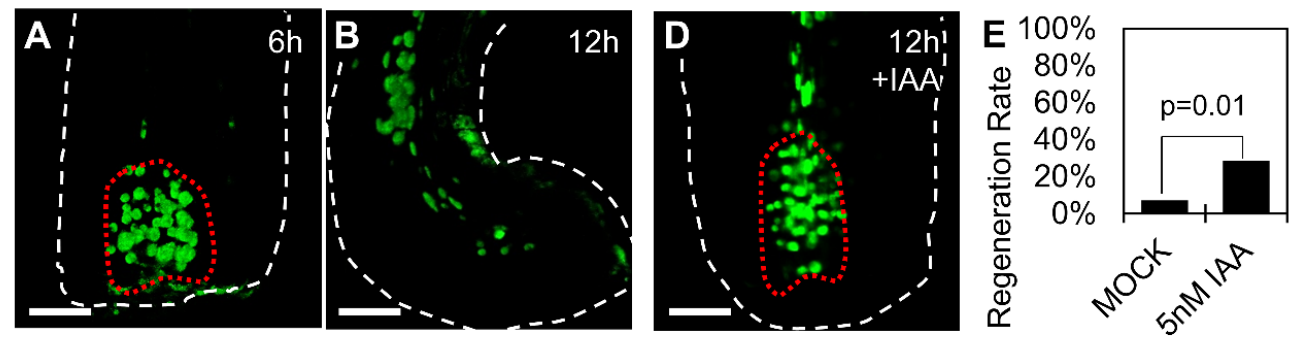

C
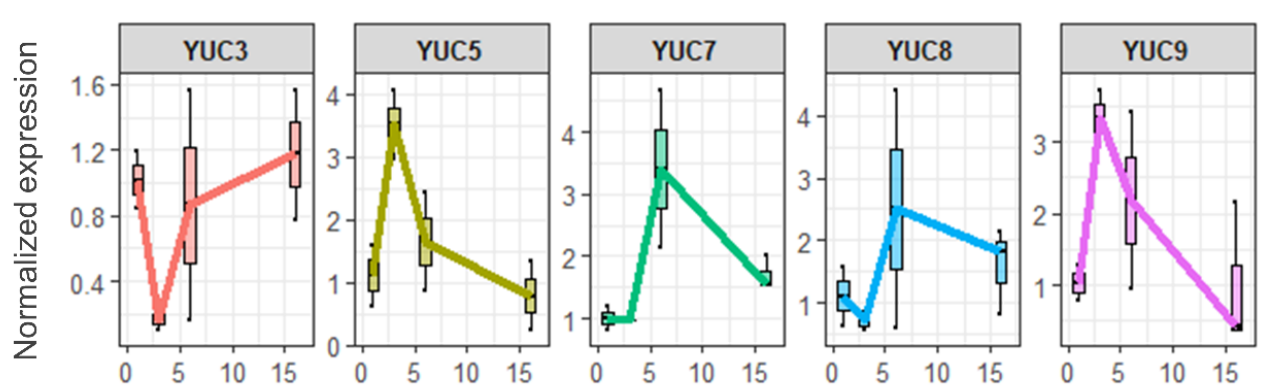

405

Hours after cut

406

Figure 7. Auxin is sufficient to induce regeneration in high-cut roots. A-B) Confocal

407 images of roots expressing DR5rev:3xVENUS-N7 and cut at 220 $\mu \mathrm{m}$ from the QC, at $6 \mathrm{hpc}$

408 (A) or $12 \mathrm{hpc}$ (B). C) qRT-PCR measurement of YUC expression in isolated meristems of

409 regenerating roots cut at $220 \mu \mathrm{m}$. Expression was normalized to levels in meristems

410 immediately after cut. D) DR5rev:3xVENUS-N7 of high-cut roots at $12 \mathrm{hpc}$ treated with $5 \mathrm{nM}$

411 IAA. E) Regeneration rates of roots cut at $220 \mu \mathrm{m}$ from the QC and treated with 5nM IAA ( $\chi$ -

412 test; $\mathrm{n}=84,84$, for WT and 5nM IAA, respectively). 
bioRxiv preprint first posted online Sep. 26, 2019; doi: http://dx.doi.org/10.1101/783480. The copyright holder for this preprint (which was not peer-reviewed) is the author/funder, who has granted bioRxiv a license to display the preprint in perpetuity.

All rights reserved. No reuse allowed without permission.

\section{Material and Methods}

415 Plant material and growth conditions $y u c Q$ and ERF115-SRDX were previously described 416 and characterized (Heyman et al., 2013; Chen et al., 2014a). The enhancer trap line J0571, 417 SCR:GFP, pDR5rev:3XVENUS-N7, TAA1p:GFP-TAA1, WOX5:mCherry WOL:GFP and the 418 SCR clone marker lines were previously described (Wysocka-Diller et al., 2000; Heisler et 419 al., 2005; Stepanova et al., 2008; Efroni et al., 2016). Arabidopsis Col-O plants were grown 420 on agar medium (0.5X Murashige and Skoog (MS), $0.5 \%$ sucrose, $0.8 \%$ agar), under long-day 421 conditions ( $16 \mathrm{~h} \mathrm{light} \mathrm{and} 8 \mathrm{~h}$ dark), at $20^{\circ} \mathrm{C}$, for 7 days. For NPA treatments, 7 -day-old plants

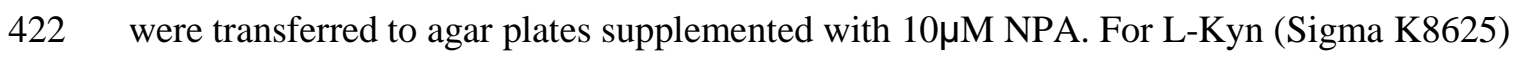
423 treatment, 7-day-old plants were transferred to agar plates supplemented with $100 \mu \mathrm{M} \mathrm{L-Kyn}$, unless indicated otherwise. For L-Kyn + IAA-treatmed plants were transferred to agar plates supplemented with $100 \mu \mathrm{M}$ L-Kyn and 100nM IAA. For split plate assays, plants were transferred to agar plates containing a barrier, with half of the plate containing $20 \mu \mathrm{M} \mathrm{L-Kyn}$ and half containing $20 \mu \mathrm{M}$ L-Kyn and 10nM IAA.

428 Root cutting assay and statistical analysis 7 -day-old seedlings were cut $120 \mu \mathrm{M}$ or $220 \mu \mathrm{M}$ above the QC, according to (Sena et al., 2009). Between 2 and 4 independent cutting sessions 430 (batches) were used for each experiment, each with a matching WT or mock control. To 431 calculate statistical significance while accounting for batch effects, we used a logistic 432 regression (models were Regenerated Genotype+Batch or Regenerated Treatment+Batch). 433 Tukey HSD was used to derive the p-values for specific contrasts. To calculate batchcorrected regeneration rates, the regeneration rate of each treatment/genotype was normalized to the regeneration rate of WT/mock-treated plants of the same batch. All analyses were 436 performed in R 3.5.2.

437 Transgenic lines All transgenic lines were generated using the golden gate cloning and the 438 MoClo system (Engler et al., 2009) and were inserted to WT Col-O background. Promoter 439 WOX5 was designed using the 4463bp fragment upstream to the first ATG of the WOX5 440 gene. Promoter YUC9 was designed using the 3895bp fragment upstream to the first ATG of 441 the YUC9 gene. Promoter AHP6 was designed using the 5079bp fragment upstream to the 442 first ATG of the AHP6 gene. amirYUC was synthesized as a cistronic diMir, with two 443 AtMir159a backbones. Sequence for amirYUC and primers are listed in Supplemental Table S2.

445 Microscopy Roots were observed using a Leica SP8 confocal microscope with x20 or x63 water objectives. Propidium iodide solution $(0.01 \mu \mathrm{g} / \mathrm{ml})$ was used to stain the cell wall. A 552 $\mathrm{nm}$ and $488 \mathrm{~nm}$ lasers were used for excitation of GFP/YFP and mCherry/PI, respectively. 
bioRxiv preprint first posted online Sep. 26, 2019; doi: http://dx.doi.org/10.1101/783480. The copyright holder for this preprint (which was not peer-reviewed) is the author/funder, who has granted bioRxiv a license to display the preprint in perpetuity.

All rights reserved. No reuse allowed without permission.

448 Meristem isolation Six-day old plants were either cut at their root tips or transferred whole to

449 liquid protoplast solution (3\% cellulose, $1 \%$ macerozyme, 0.4M mannitol, $20.48 \mathrm{mM}$ MES,

$\left.450 \quad 0.02 \mathrm{M} \mathrm{KCl}(1 \mathrm{M}), 0.1 \% \mathrm{BSA}, 0.02 \mathrm{M} \mathrm{CaCl}_{2}, \mathrm{pH} 5.7\right)$ for a $10-15$ minutes incubation period.

451 The liquid solution caused the dissociation of the meristems at the transition zone. Meristems

452 were then collected using a pipette, rinsed with DDW, and flash frozen, followed by RNA

453 extraction using the QIAGEN RNeasy ${ }^{\mathrm{TM}}$ micro-kit according to the manufacturer's protocol.

454 RNA-seq analysis Libraries were prepared using the 3' mRNA-QuantSeq kit (Lexogen)

455 according to the manufacturer's instructions, followed by sequencing using NextSeq 500

456 (Illumina). Sequences were aligned to the TAIR10 genome using Bowtie2; gene expression

457 hits were computed using htseq-count. To account for 3' mis-annotation, the 3' of all genes

458 was extended 500bp downstream. Normalization and significance calling was performed

459 using DeSeq2. Experiments were performed in 2, 3 or 5 replicates.

460 qRT analysis RNA was extracted using the RNeasy micro-kit (Qiagen), following by cDNA

461 synthesis using qPCRBIO cDNA Synthesis Kit (PCR BIOSYSTEMS). Real-time PCR was

462 performed using Fast SYBR® Green Master Mix (Rhenium) with a final primer concentration

463 of $0.2 \mu \mathrm{M}$. Primers are listed in Supplemental Table S2.

464 Acknowledgments

465 We thank Jose Alonso, Anna Stepanova and Lieven de Veylder for sharing research material.

466 We thank Yuval Eshed and Sigal Savaldi-Goldstein for comments and discussions. IE is

467 supported by the Israeli Science Foundation (ISF966/17) and the Howard Hughes Medical

468 Institute International Research Scholar Grant (55008730).

469 Accession Numbers

470 RNA-seq data were deposited in GEO (GEO series). 
bioRxiv preprint first posted online Sep. 26, 2019; doi: http://dx.doi.org/10.1101/783480. The copyright holder for this preprint (which was not peer-reviewed) is the author/funder, who has granted bioRxiv a license to display the preprint in perpetuity.

All rights reserved. No reuse allowed without permission.

Supplemental Figures

A $5 0 0 \longdiv { C }$

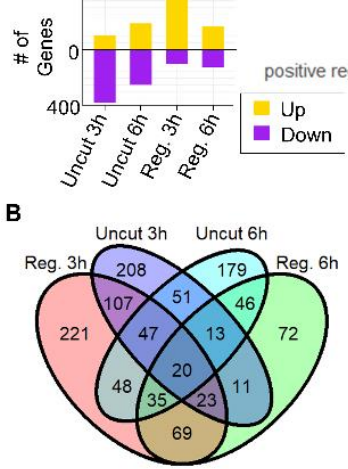

C

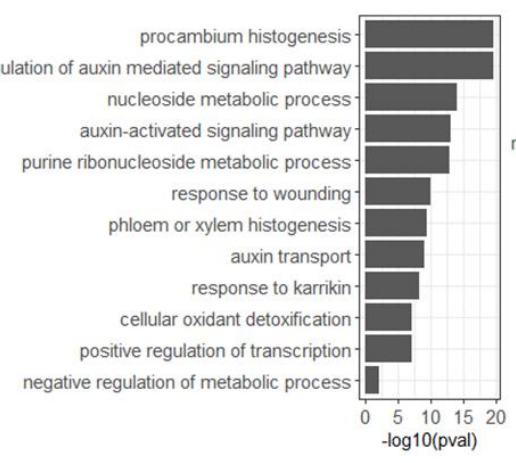

D

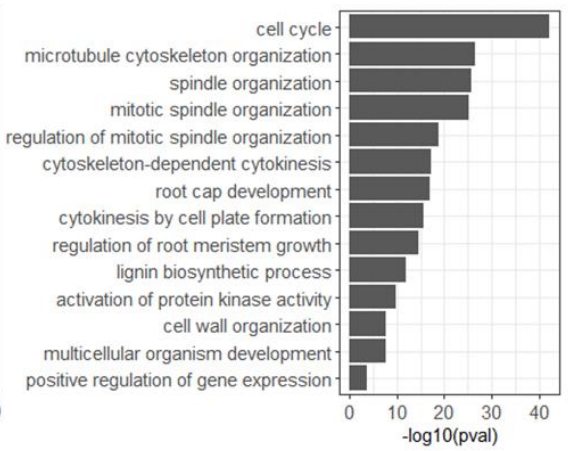

473

474 Supplementary Figure S1. Analysis of gene expression changes in regenerating roots

475 treated with L-Kyn. A) Number of genes whose expression was modified by L-Kyn in cut

476 and uncut roots. B) Venn diagram of the modified genes of regenerating (Reg.) or uncut root

477 meristems following $3 \mathrm{~h}$ and $6 \mathrm{~h}$ of L-Kyn treatment. Genes specifically modified by L-Kyn in

478 regenerating roots, and used for downstream analysis. C-D) Enriched GO terms for genes

479 suppressed by L-Kyn treatment in regenerating root tips at $3 \mathrm{hpc}(\mathrm{C})$ and $6 \mathrm{hpc}(\mathrm{D})$. 
bioRxiv preprint first posted online Sep. 26, 2019; doi: http://dx.doi.org/10.1101/783480. The copyright holder for this preprint (which was not peer-reviewed) is the author/funder, who has granted bioRxiv a license to display the preprint in perpetuity.

All rights reserved. No reuse allowed without permission.
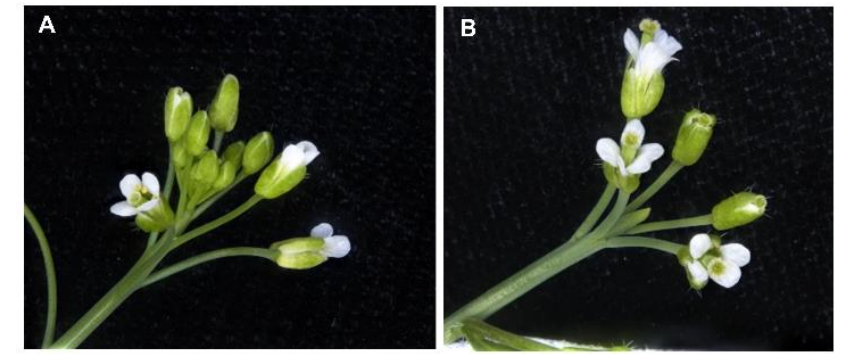

482

483 Supplemental Figure S2. Strong lines of pYUC9:amiRYUC develop pin-like terminated meristems. A) WT floral meristem. B) pYUC9:amiRYUC pin-like floral meristem. 

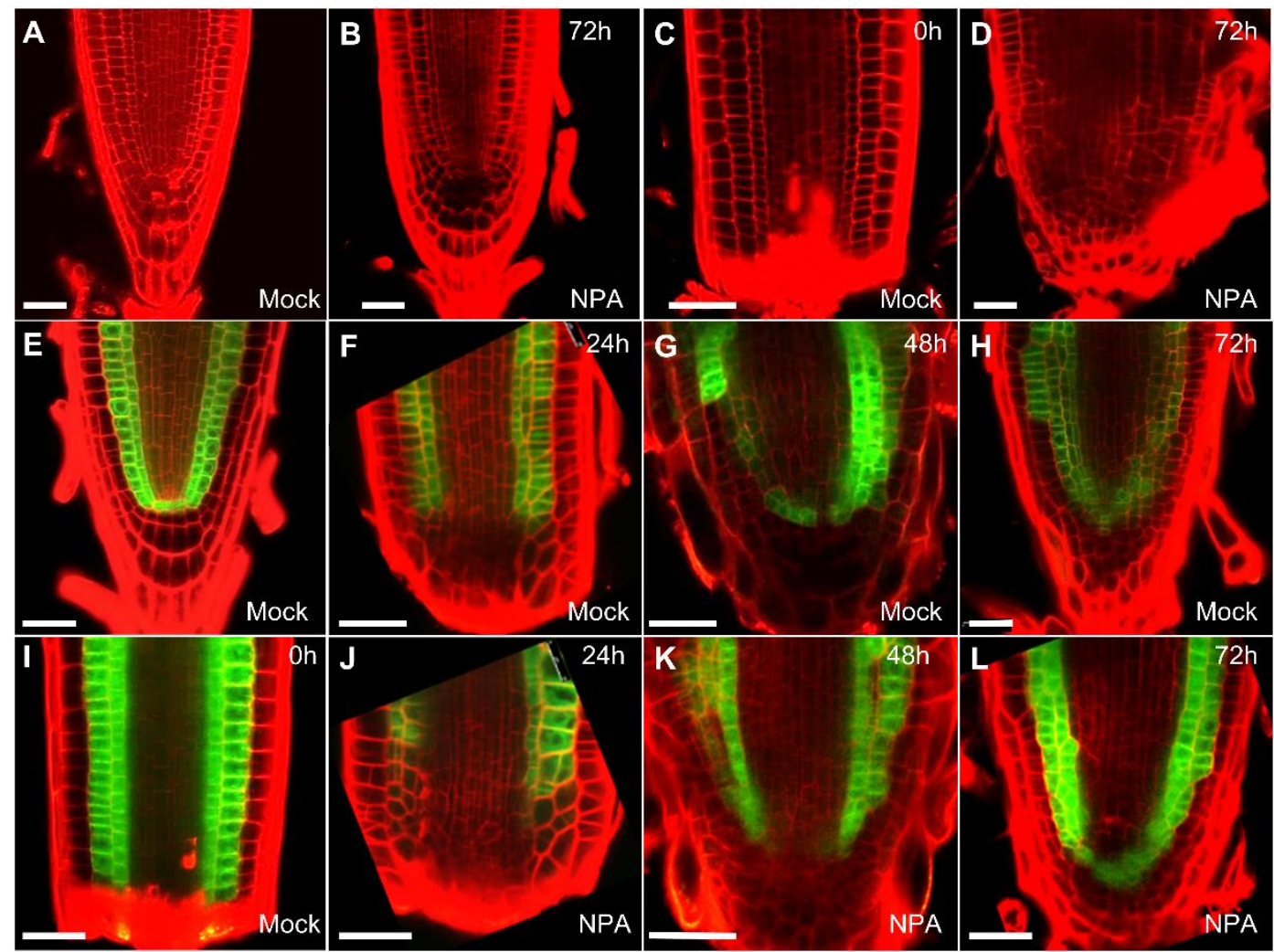

487 Supplemental Figure S3. Regeneration and tissue pattern recovery in the presence of

488 NPA. A-D) Confocal images of uncut (A-B) or cut (C-D) 7 DAS roots before (A,C) or after

$48972 \mathrm{~h}$ of $10 \mu \mathrm{M}$ NPA treatment (B,D). E-L) Confocal images of the ground tissue marker J0571

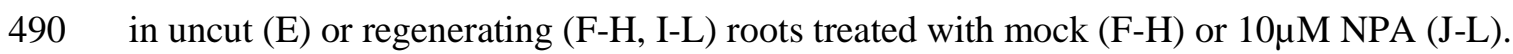

491 Scale bar: $50 \mu \mathrm{m}$. 

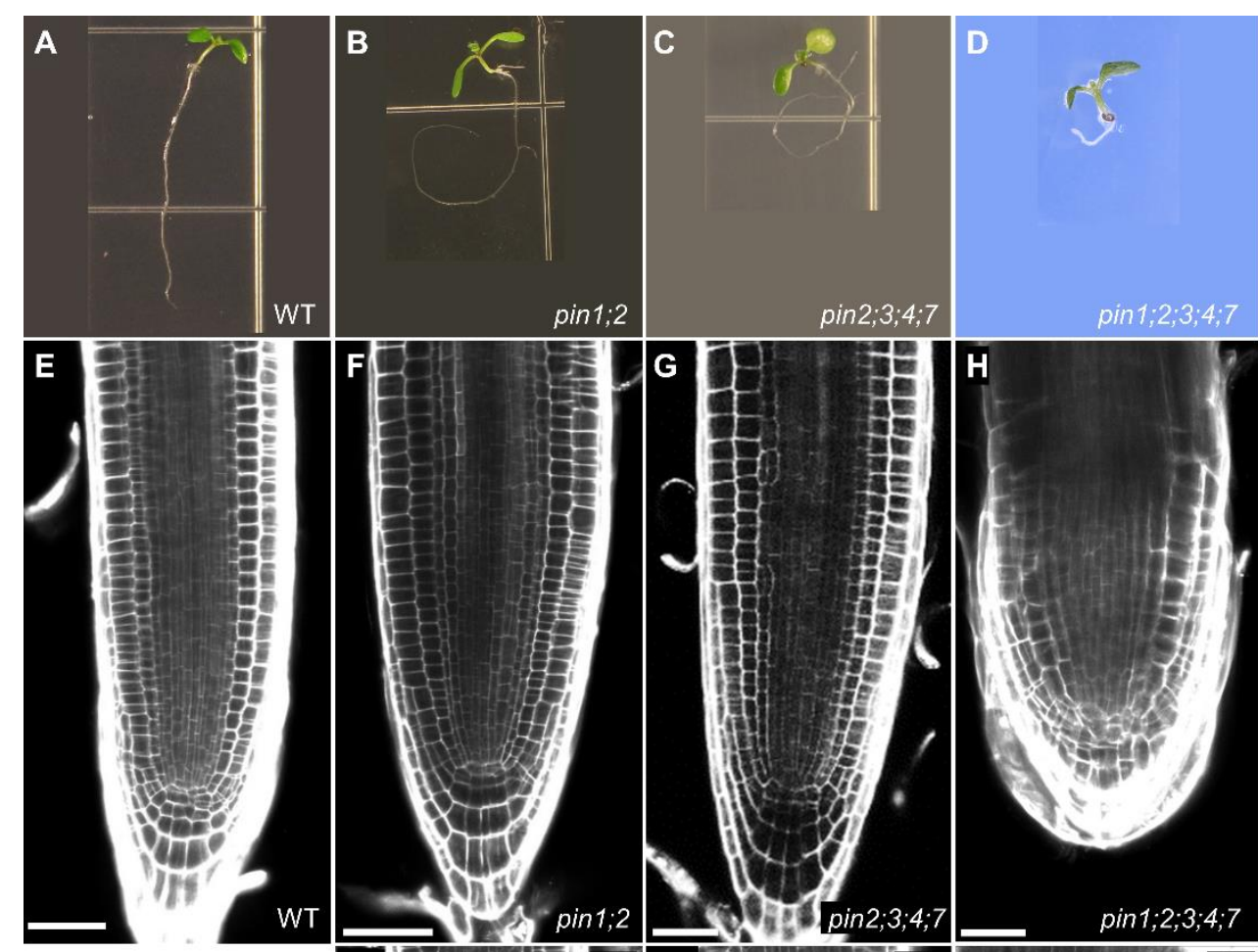

492
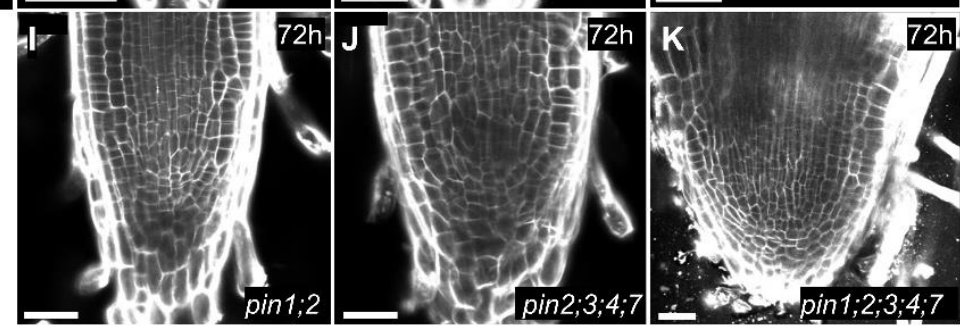

493 Supplementary Figure S4. Root meristem growth, morphology and regeneration of

494 high-order pin mutants. A-D) Images of 7 DAS WT (A) and pin mutants (B-D). E-I)

495 Confocal images of uncut (E-H) or regenerating roots at $72 \mathrm{hpc}(\mathrm{F}-\mathrm{I})$ of WT (E) and pin

496 mutants (F-K) Scale bars are $5 \mathrm{~mm}$ in (A-D) and 50 $\mu \mathrm{m}(\mathrm{E}-\mathrm{K})$.

497

498 

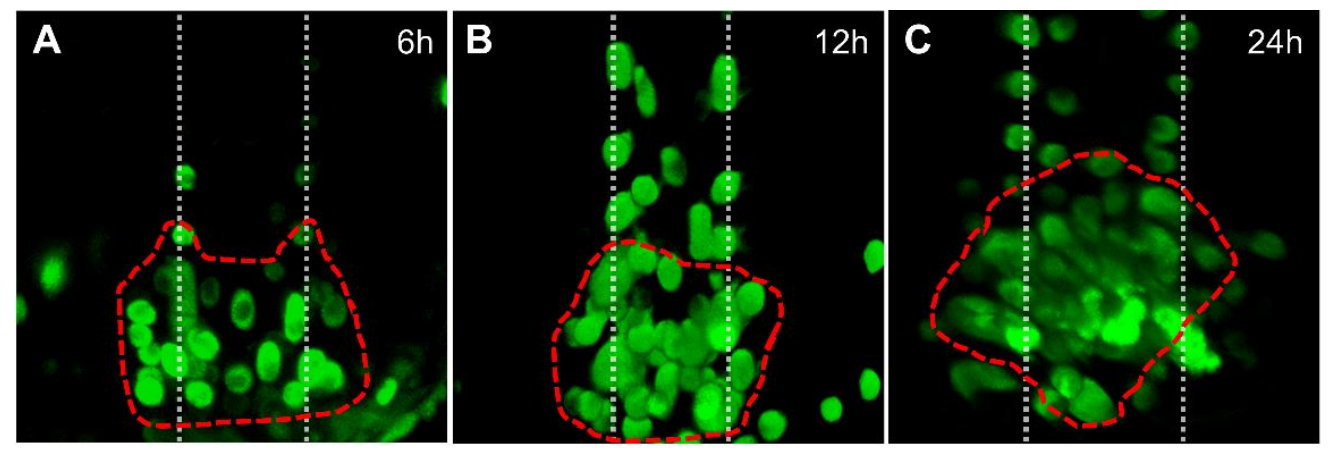

499

500 Supplemental Figure S5. Regeneration of big mutants. A-C) Close-up of the regeneration

501 region of big DR5rev:3xVENUS-N7 plants during regeneration.

503 Supplemental Table S1. Genes modified by L-Kyn at $3 \mathrm{~h}$ and $6 \mathrm{~h}$.

504 Supplemental Table S2. Primers and synthesized microRNAs used in this study. 
bioRxiv preprint first posted online Sep. 26, 2019; doi: http://dx.doi.org/10.1101/783480. The copyright holder for this preprint (which was not peer-reviewed) is the author/funder, who has granted bioRxiv a license to display the preprint in perpetuity.

All rights reserved. No reuse allowed without permission.

\section{References}

Adamowski M, Friml J (2015) PIN-Dependent Auxin Transport: Action, Regulation, and Evolution. Plant Cell 27, 20-32

Bahieldin A, Atef A, Edris S, Gadalla NO, Ramadan AM, Hassan SM, Al Attas SG, AlKordy MA, Al-Hajar ASM, Sabir JSM, et al (2018) Multifunctional activities of ERF109 as affected by salt stress in Arabidopsis. Sci Rep 8, 1-10

Blilou I, Xu J, Wildwater M, Willemsen V, Paponov I, Friml J, Heidstra R, Aida M, Palme K, Scheres B (2005) The PIN auxin efflux facilitator network controls growth and patterning in Arabidopsis roots. Nature 433, 39-44

Brady SM, Orlando DA, Lee J-Y, Wang JY, Koch J, Dinneny JR, Mace D, Ohler U, Benfey PN (2007) A high-resolution root spatiotemporal map reveals dominant expression patterns. Science 318, 801-6

Brumos J, Robles LM, Yun J, Vu TC, Jackson S, Alonso JM, Stepanova AN (2018) Local Auxin Biosynthesis Is a Key Regulator of Plant Development. Dev Cell 47, 306-318.e5

Bustillo-Avendaño E, Ibáñez S, Sanz O, Sousa Barros JA, Gude I, Perianez-Rodriguez J, Micol JL, Del Pozo JC, Moreno-Risueno MA, Pérez-Pérez JM (2018) Regulation of Hormonal Control, Cell Reprogramming, and Patterning during De Novo Root Organogenesis. Plant Physiol 176, 1709-1727

Chen L, Tong J, Xiao L, Ruan Y, Liu J, Zeng M, Huang H, Wang J-W, Xu L (2016) YUCCA-mediated auxin biogenesis is required for cell fate transition occurring during de novo root organogenesis in Arabidopsis. J Exp Bot 67, 4273-84

Chen Q, Dai X, De-Paoli H, Cheng Y, Takebayashi Y, Kasahara H, Kamiya Y, Zhao Y (2014a) Auxin Overproduction in Shoots Cannot Rescue Auxin Deficiencies in Arabidopsis Roots. Plant Cell Physiol 55, 1072-1079

Chen X, Qu Y, Sheng L, Liu J, Huang H, Xu L (2014b) A simple method suitable to study de novo root organogenesis. Front Plant Sci 5, 1-6

Cheng Y, Qin G, Dai X, Zhao Y (2007) NPY1, a BTB-NPH3-like protein, plays a critical role in auxin-regulated organogenesis in Arabidopsis. Proc Natl Acad Sci 104, 18825-18829

Druege U, Franken P, Hajirezaei MR (2016) Plant Hormone Homeostasis, Signaling, and Function during Adventitious Root Formation in Cuttings. Front Plant Sci 7, 1-14

Efroni I (2018) A Conceptual Framework for Cell Identity Transitions in Plants. Plant Cell Physiol 59, 696-706

Efroni I, Mello A, Nawy T, Ip P, Rahni R, DelRose N, Powers A, Satija R, Birnbaum KD (2016) Root Regeneration Triggers an Embryo-like Sequence Guided by Hormonal Interactions. Cell 165, 1721-33

Engler C, Gruetzner R, Kandzia R, Marillonnet S (2009) Golden gate shuffling: A one-pot DNA shuffling method based on type ils restriction enzymes. PLoS One. doi: 10.1371/journal.pone. 0005553

Feldman LJ (1976) The de novo origin of the quiescent center regenerating root apices of Zea mays. Planta $128,207-212$

Gil P, Dewey E, Friml J, Zhao Y, Snowden KC, Putterill J, Palme K, Estelle M, Chory J (2001) BIG: A calossin-like protein required for polar auxin transport in Arabidopsis. Genes Dev 15, 1985-1997 
bioRxiv preprint first posted online Sep. 26, 2019; doi: http://dx.doi.org/10.1101/783480. The copyright holder for this preprint (which was not peer-reviewed) is the author/funder, who has granted bioRxiv a license to display the preprint in perpetuity.

All rights reserved. No reuse allowed without permission.

Grieneisen VA, Xu J, Marée AFM, Hogeweg P, Scheres B (2007) Auxin transport is sufficient to generate a maximum and gradient guiding root growth. Nature 449, $1008-$ 13

He W, Brumos J, Li H, Ji Y, Ke M, Gong X, Zeng Q, Li W, Zhang X, An F, et al (2011) A Small-Molecule Screen Identifies 1-Kynurenine as a Competitive Inhibitor of TAA1/TAR Activity in Ethylene-Directed Auxin Biosynthesis and Root Growth in Arabidopsis . Plant Cell 23, 3944-3960

Heidstra R, Sabatini S (2014) Plant and animal stem cells: Similar yet different. Nat Rev Mol Cell Biol 15, 301-312

Heisler MG, Ohno C, Das P, Sieber P, Reddy G V., Long J a., Meyerowitz EM (2005) Patterns of auxin transport and gene expression during primordium development revealed by live imaging of the Arabidopsis inflorescence meristem. Curr Biol 15, 1899-1911

Heyman J, Cools T, Canher B, Shavialenka S, Traas J, Vercauteren I, Van den Daele H, Persiau G, De Jaeger G, Sugimoto K, et al (2016) The heterodimeric transcription factor complex ERF115-PAT1 grants regeneration competence. Nat Plants 2, 16165

Heyman J, Cools T, Vandenbussche F, Heyndrickx KS, Leene J Van, Straeten D Van Der, Veylder L De (2013) ERF115 Controls Root Quiescent Center Cell Division and Stem Cell Replenishment. 761, 860-864

Kareem A, Durgaprasad K, Sugimoto K, Du Y, Pulianmackal AJ, Trivedi ZB, Abhayadev P V, Pinon V, Meyerowitz EM, Scheres B, et al (2015) PLETHORA Genes Control Regeneration by a Two- Step Mechanism PLETHORA Genes Control Regeneration by a Two-Step Mechanism. Curr Biol 25, 1-14

Kneuper I, Teale WD, Dawson JE, Tsuggeki R, Palme K, Katifori E, Ditengou FA (2017) Tissue specific auxin biosynthesis regulates leaf vein patterning. bioRxiv 184275

Ohashi-Ito K, Iwamoto K, Nagashima Y, Kojima M, Sakakibara H, Fukuda H (2019) A positive feedback loop comprising LHW-TMO5 and local auxin biosynthesis regulates initial vascular development in Arabidopsis roots. Plant Cell Physiol 1-36

Petersson S V., Johansson AI, Kowalczyk M, Makoveychuk A, Wang JY, Moritz T, Grebe M, Benfey PN, Sandberg G, Ljung K (2009) An auxin gradient and maximum in the Arabidopsis root apex shown by high-resolution cell-specific analysis of IAA distribution and synthesis. Plant Cell 21, 1659-68

Petrásek J, Cerná A, Schwarzerová K, Elckner M, Morris DA, Zazímalová E (2003) Do phytotropins inhibit auxin efflux by impairing vesicle traffic? Plant Physiol 131, 254-63

Reinhardt D, Frenz M, Mandel T, Kuhlemeier C (2003) Microsurgical and laser ablation analysis of interactions between the zones and layers of the tomato shoot apical meristem. Development 130, 4073-4083

Robert HS, Crhak Khaitova L, Mroue S, Benková E (2015) The importance of localized auxin production for morphogenesis of reproductive organs and embryos in Arabidopsis. $\mathrm{J}$ Exp Bot 66, 5029-5042

Robert HS, Grones P, Stepanova AN, Robles LM, Lokerse AS, Alonso JM, Weijers D, Friml J (2013) Local auxin sources orient the apical-basal axis in arabidopsis embryos. Curr Biol 23, 2506-2512

Sabatini S, Beis D, Wolkenfelt H, Murfett J, Guilfoyle T, Malamy J, Benfey P, Leyser O, Bechtold N, Weisbeek P, et al (1999) An Auxin-Dependent Distal Organizer of Pattern and Polarity in the Arabidopsis Root. Cell 99, 463-472 
bioRxiv preprint first posted online Sep. 26, 2019; doi: http://dx.doi.org/10.1101/783480. The copyright holder for this preprint (which was not peer-reviewed) is the author/funder, who has granted bioRxiv a license to display the preprint in perpetuity.

All rights reserved. No reuse allowed without permission.

Santuari L, Sanchez-Perez GF, Luijten M, Rutjens B, Terpstra I, Berke L, Gorte M, Prasad K, Bao D, Timmermans-Hereijgers JLPM, et al (2016) The PLETHORA Gene Regulatory Network Guides Growth and Cell Differentiation in Arabidopsis Roots. Plant Cell 28, 2937-2951

Scarpella E, Marcos D, Friml J, Berleth T (2006) Control of leaf vascular patterning by polar auxin transport. Genes Dev 20, 1015-1027

Schaller GE, Bishopp A, Kieber JJ (2015) The yin-yang of hormones: cytokinin and auxin interactions in plant development. Plant Cell 27, 44-63

Sena G, Wang X, Liu H-Y, Hofhuis H, Birnbaum KD (2009) Organ regeneration does not require a functional stem cell niche in plants. Nature $457,1150-3$

Stepanova AN, Robertson-Hoyt J, Yun J, Benavente LM, Xie DY, Doležal K, Schlereth A, Jürgens G, Alonso JM (2008) TAA1-Mediated Auxin Biosynthesis Is Essential for Hormone Crosstalk and Plant Development. Cell 133, 177-191

Sztein AE, Ilić N, Cohen JD, Cooke TJ (2002) Indole-3-acetic acid biosynthesis in isolated axes from germinating bean seeds: The effect of wounding on the biosynthetic pathway. Plant Growth Regul 36, 201-207

Tsugafune S, Mashiguchi K, Fukui K, Takebayashi Y, Nishimura T, Sakai T, Shimada Y, Kasahara H, Koshiba T, Hayashi K (2017) Yucasin DF, a potent and persistent inhibitor of auxin biosynthesis in plants. Sci Rep 7, 13992

Ulmasov T, Liu ZB, Hagen G, Guilfoyle TJ (1995) Composite structure of auxin response elements. Plant Cell 7, 1611-23

Verna C, Ravichandran SJ, Sawchuk MG, Linh M, Scarpella E (2019) Coordination of Tissue Cell Polarity by Auxin Transport and Signaling. bioRxiv

Weijers D, Wagner D (2016) Transcriptional Responses to the Auxin Hormone. Annu Rev Plant Biol 67, annurev-arplant-043015-112122

Wysocka-Diller JW, Helariutta Y, Fukaki H, Malamy JE, Benfey PN (2000) Molecular analysis of SCARECROW function reveals a radial patterning mechanism common to root and shoot. Development 127, 595-603

Xu D, Miao J, Yumoto E, Yokota T, Asahina M, Watahiki M (2017) YUCCA9-Mediated Auxin Biosynthesis and Polar Auxin Transport Synergistically Regulate Regeneration of Root Systems Following Root Cutting. Plant Cell Physiol 0, 1-14

Xu J, Hofhuis H, Heidstra R, Sauer M, Friml J, Scheres B (2006) A molecular framework for plant regeneration. Science $311,385-8$

Xu M, Hu T, Zhao J, Park MY, Earley KW, Wu G, Yang L, Poethig RS (2016) Developmental Functions of miR156-Regulated SQUAMOSA PROMOTER BINDING PROTEIN-LIKE (SPL) Genes in Arabidopsis thaliana. PLoS Genet 12, 1-29

Zhao Y (2010) Auxin biosynthesis and its role in plant development. Annu Rev Plant Biol 61, 49-64

Zhao Y (2018) Essential Roles of Local Auxin Biosynthesis in Plant Development and in Adaptation to Environmental Changes. Annu Rev Plant Biol 69, 417-435

Zhou W, Lozano-Torres JL, Blilou I, Zhang X, Zhai Q, Smant G, Li C, Scheres B (2019) A Jasmonate Signaling Network Activates Root Stem Cells and Promotes Regeneration. Cell 1-15 